4. Zakharchuk, O. A. (2011). Tematicheskaya klassifikatsiya voyennogo zhargona kak otrazheniye professional'nogo vospriyatiya voyennosluzhashchikh. [Thematic classification of military jargon as a reflection of the professional perception of military personnel]. Vestnik Chelyabinskogo gosudarstvennogo universiteta. Filologiya. Iskusstvovedeniye. Chelyabinsk, vol. 57, no 24 (239), pp. 224-226.

5. Boyko, B. L. (2008). Yazykovaya kartina mira armeyskoy subkul'tury [Linguistic picture of the world of army subculture]. Vestnik Voyennogo universiteta, no 4, pp. 96-102.

6. Shevel'ov, Yu. (1996). Dvomovnist' i vul'haryzmy [Bilingualism and Vulgarisms]. Vydatnyy filoloh suchasnosti (Naukovi vyklady na chest' 85-littya Yuriya Shevel'ova). [An outstanding philologist of the present (Scientific Presentations in Honor of the 85th Anniversary of Yuri Shevelyov)]. Kharkiv.

\title{
DECLENSION OF MASCULINE NAMES AND DECLENSION OF HARD GROUP IN MODERN UKRAINIAN LITERARY LANGUAGE
}

\section{Julia Akhmedova ${ }^{1}$}

DOI: https://doi.org/10.30525/978-9934-588-11-2_40

Formulation of the issue. The morphological paradigms of anthroponyms names of individuals - are included in the inflection system of lexical and grammatical categories of the noun. Compared with appellatives, in the declination process they reveal many specific features. The inflectional paradigm issues of the number of classes and subclasses of numb were studied by I. I. Kovalyk, Yu. K. Redko, P. P. Chuchka, L. P. Kalakutska, A. A. Zalizniak, L. T. Masenko, V. O. Horpynych, I M. Zheliezniak, N. P. Dziatkivska, L. G. Skrypnyk, S. I. Holovashchuk, S. L. Kovtiukh, O. M. Kashtalian and others. Despite the longstanding tradition of studies of word-changing paradigms of anthroponyms, in modern domestic linguistics there is no comprehensive description of the distinctive forms of Ukrainian proper masculine and feminine names, taking into account extraand intralingual factors.

The relevance of the study is due to the need for the systematic analysis of the morphological paradigms of Ukrainian names of individuals and the identification of the number of EPCs (elementary paradigmatic classes) of anthroponyms of the first declension of the hard group to indicate males.

The purpose of the article is to analyze inflectional paradigms in the singular and plural of Ukrainian proper male names and their variants, taking into account the necessary factors. Realization of the goal involves the following tasks: 1) consider the influence of morphological name categories on the selection of case endings of the studied subclass of anthroponyms; 2) establish other criteria for determining inflectional paradigms of proper masculine names; 3) characterize highlighted EPCs of the I declension of the hard group.

\footnotetext{
${ }^{1}$ Volodymyr Vynnychenko Central Ukrainian State Pedagogical University, Ukraine
} 
Presentation of the main material. In Ukrainian language, the modern first declension of nouns is made up of feminine as well as masculine and dual gender with inflection -a after a solid phoneme (spelling - $\mathbf{r}$ - after soft) in the nominative singular and substantive with magnifying suffix -ищ-, «if they express feminine gender» [1, p. 197].

The analysis of the system of factors that determine the distinct paradigms of Ukrainian surnames, in particular the anthropolexemes of the first declension of the hard group, and their EPCs are presented in the monograph S. L. Kovtiukh, O. M. Kashtalian «The Inflectional Paradigmatics of Ukrainian Surnames» (2012) [2, p. 45-62].

The following criteria are relevant for the distinctive paradigms of Ukrainian proper masculine names of the first declension of the hard group: nominal inflection type; generic attribution (marking by the category of masculine gender) belonging to the category of creatures-personalities; the uniformity of accentuation paradigms (the same fixed emphasis or only on the basis in the case forms of the singular and plural, or at the end) the formation of complete paradigms; community of case endings; the choice of the inflection of the genitive plural (-iв or zero); -o ending in the singular vocative; the presence of doublet forms in the plural accusative; morphological phenomena at the base of lexemes associated with inflection, namely: the alternation of hard and soft phonemes, hard rear-lingual with soft front-lingual whistling, loud phoneme /o/ with zero.

In our card files, 86 lexemes have been attested for the designation of male names of the 1st declension of the hard group, recorded in the lexicographic works «Proper names of people» (2005) L. G. Skrypnyk, N. P. Dziatkivska and «Dictionary of Ukrainian Names» I. I. Triiniak (2005). Among them are 28 full official anthroponyms - Микола [4, p. 77], Са́вка [4, p. 96], Хома́ [4, p. 108] and others: А скільки сонць ми зустрічали, сусіде мій Миколо Чалий?! (V. Marsiuk). Савка вийтов із своєї хатки і дивився на нас як намальований. Він продовжував 3 Савкою свою розмову, образливу і гірку для нас. - Савко! - крикнув Платон до сусідньої хати. - Ходім, Савко (О. Dovzhenko). Будемо як Хома Брут, тільки над ним один гроб літав, а над нами буде багато, з космічним свистом (L. Kostenko). 58 variants of anthropolexemes are verified to indicate unofficial forms of proper names - Во́вка (від Володи́мир) [4, p. 48], Жо́ра (від Гео́ргій; Єго́p; Юрій, Юрко́) [4, p. 51], Йо́ська (від Йо́сun, О́сип (Йо́сиф)) [4, p. 65] and others: Вовка зачерпнув довбанкою теплого узвару (V. Blyznets). Після розмови з Жорою у Віктора на душі лишився не вельми приємний осад (A. Kurkov). Bсім нашим вулииям сповна він дав блискучі імена: і Маркса, й Леніна, й Артема, $i$ Йоськи Сталіна зокрема... (V. Marsiuk).

For the case paradigms of Ukrainian proper masculine names of the first declension of the hard group in the singular nominative case is characterized by flexion $\mathbf{- a}$, in the genitive case $-\mathbf{- n}$, the dative case $-\mathbf{- i}$, the accusative case $-\mathbf{- y}$, the instrumental case $-\mathbf{- 0 1 0}$, the local case $-\mathbf{- i}$, the vocal case $-\mathbf{- 0}$, in the plural nominative case $\mathbf{-}-\mathbf{n}$, in the genitive case - zero / -ib, dative case - -am, accusative

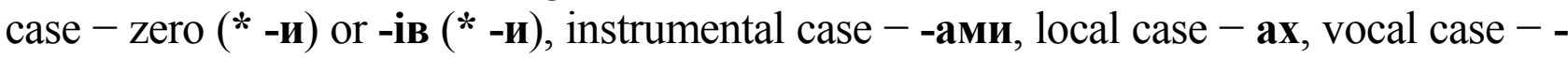
и. It is worth paying attention to the fact that the accusative case of the plural 
masculine names of the 1st declension of the hard group is characterized by doublet forms, homonymic with the word forms of the genitive case (Гри́шок, Йо́ньок, Олекс) and the plural nominative forms with the preposition у (в) (податися в Гри́шки, мітити в Йо́ньки, прагнути в Олекси), which are emphasized by Professor S. L. Kovtiukh [3, p. 50-51].

Considering the relevant factors for distinguishing the paradigms of masculine names of the 1st declension of the hard group, 7 EPCs were identified.

EPC No. 1 (Azána) includes anthropo-names Дїма (від Дмитро́; Димитріáн), Йо́ва (від Іо́в, Йов), Оре́фа, Кóna (від Про́кіn, Проко́niŭ), Яре́ма and others. They are characterized by the fixed emphasis based on the declension forms of the singular and plural sub-paradigms, zero flexion in the form of the generic plural singular (Bов, Iв, Ром, Стьоn, Тім), zero and -и - in the plural accusative (Bара́в $\left({ }^{*}\right.$ y Bapáвu)).

ЕPC No. 2 (Аки́ла) combines anthroponyms Васю́та (від Васи́ль; Васи́лько), Меле́та (від Меле́тіŭ), Си́ла, Си́са (від Сисо́й) and others, which are characterized by the same fixed emphasis based on singular and plural forms and zero flexion in the form of the genitive and one form of the accusative plural form: Ахіл, Ген, Мики́m, Кузьминн. The alternation of hard / soft phonemes is verified in the dative and local singular: /д/ - /д'/ (Юда - Ю́дi, на, у (в), при, по Ю́ді), л/ - /л'/ (Ваку́ла - Ваку́лі,

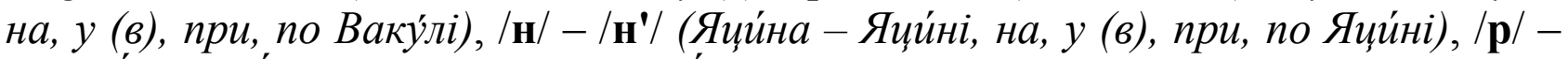
/p'/ (Юра - Юрi, на, у (в), при, по Юрi), /c/ - /с'/ (Оле́кса - Оле́ксі, на, у (в), при,

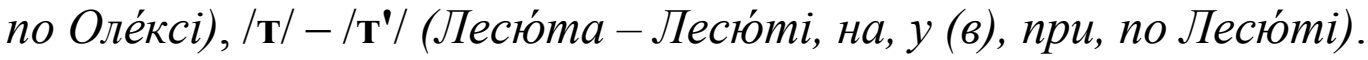

EPC No. 3 (Гapáxa) includes such names with the fixed emphasis from all forms of declensions: Матю́xа (від Матвїй (Матій, Матя́m)), Серьо́zа (від Сергі́й), Тимо́ха (від Тимофій. Тимім, Тимко́). The genitive plural is characterized by zero inflection (Гара́x, Тимóx), the accusative plural by zero and -и (Серьóz $\left({ }^{*} y\right.$ Серьózu)). The alternation of consonantal phonemes $/ \mathbf{x} /-/ \mathbf{c}^{\prime} /$ (Mamю́xa Матю́сі, на, у (в), при, по Матю́сi), /г/ - /3'/(Серьóza - Серьóз-i, на, у (в), при, по Серьó $3-i)$ is verified in the dative and local singular.

EPC No. 4 (Ві́mька) includes names with fixed emphasis in singular and plural: Ві́тічка (від Ві́ктор, Вікто́рій, Віктори́н), Гри́шка (від Григо́рій, Гри́гір), Мики́тка (від Мики́та), Ко́лька (від Мико́ла (Микола́й, Нико́ла)), Чі́пка (від Ники́фор, Ничи́пір), Оле́жка (від Оле́г) and others. In the form of genitive plural, the analyzed anthroponyms have zero flexion: Во́вочок, Ко́тьок, Про́шок, Ро́мок. Alternation of consonant phonemes $/ \mathbf{k} /-/ \mathbf{u}^{\prime} /$ (Гу́рка - Гу́риi, на, у (в), при, по Гу́риі, Дени́ска - Дени́сиі, на, у (в), при, по Дени́сиі, Іллю́шка - Іллю́шиі, на, у (в), при, по Іллю́шиі) осcurs in the dative and local singular. In addition, the alternation of the vowel phoneme /o/ with zero in the genitive and accusative plural cases is verified, since in the anthroponyms of this class in the final segment of the base there is the coincidence of two consonant phonemes (Ваню́шки - Ваню́шок, Ге́нки Ге́нок, Кузе́мки - Кузе́мок, Па́вка - Па́вок, Я́шка-я́шок).

EPC No. 5 (Куззвмá) includes one anthropolexeme that has the fixed emphasis on ending in the declension forms of the singular and plural sub-paradigms. The form of the genitive plural is characterized by flexion -і́в (Кузьмів), for the accusative plural - і́в and -и (Кузьмів (* у Кузьми́)). 
EPC No. 6 (Лука́) includes to one of anthroponym with fixed emphasis on flexion in all cases. In the form of the genitive plural the lexeme has the ending -íв (Луків), in the form of accusative plural -ís and -и (Луків (* $у$ Лукú). In the dative

and local singular there is alternation of the consonant phonemes $/ \mathbf{k} /-/ \mathbf{u}^{\prime} /($ (Лка́ Луйí, на, у (в), при, по Луйі).

ЕРС No. 7 (Хомá) combines lexemes Тома́, Фома́ that have the pronounced flexion in the singular and the emphasized basis in the plural. In the form of the genitive plural the flexion -íв (Хо́мів) is attested and in the form of the accusative the flexions -íв and -и (Хо́мів (*y Хо́ми). The nominative, accusative, and vocative plural cases are characterized by associated forms with emphasized ending ( $\partial в а-$ чотири Фоми́).

Conclusions. The article analyzes the factors of determining the anthroponyms' morphological paradigms for the designation of masculine names of the first declension of the solid group and identifies 7 EPCs. The system of morphological paradigms of Ukrainian proper masculine and feminine names requires comprehensive and detailed research, taking into account the latest approaches in linguistics.

\section{References:}

1. Vykhovanecj, I. R., Ghorodensjka, K. Gh., Zaghnitko, A. P., \& Sokolova, S. O. (2017). Hramatyka suchasnoi ukrainskoi literaturnoi movy. Morfolohiia [Grammar of Modern Ukrainian Literary Language. Morphology]. Kyiv : Vydavnychyj dim Dmytra Buragho. (in Ukrainian)

2. Kovtjukh, S. L., \& Kashtaljan, O. M. (2012). Slovozminna paradyhmatyka ukrainskykh prizvyshch : monohrafiia [The inflectional paradigm of Ukrainian surnames : a monograph]. Kirovohrad : POLIMED-Servis. (in Ukrainian)

3. Kovtjukh, S. L. (2006). Osoblyvosti morfologhichnoji paradyghmatyky onimiv suchasnoji ukrajinsjkoji movy [Features of morphological paradigm of homonym of modern Ukrainian

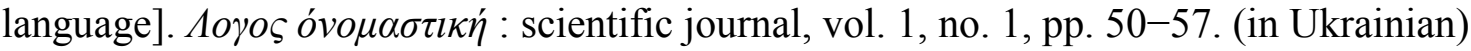

4. Skrypnyk, L. Gh., \& Dzjatkivsjka, N. P. (2005). Vlasni imena ljudej : slovnyk-dovidnyk [Own people's names reference book]. Kyiv : Naukova dumka. (in Ukrainian)

5. Trijnjak, I. I. (2005). Slovnyk ukrajinsjkykh imen [Dictionary of Ukrainian names]. Kyiv : Dovira. (in Ukrainian) 